\title{
Comparison of consumer knowledge about Campylobacter, Salmonella and Toxoplasma and their transmissibility via meat: results of a consumer study in Germany
}

\author{
K. A. Henke ${ }^{1}$, T. Alter ${ }^{2}$, M. G. Doherr ${ }^{1}$ and R. Merle ${ }^{1 *}$
}

\begin{abstract}
Background: Campylobacter is the most commonly reported causative agent of foodborne bacterial infection in Germany, and contaminated chicken meat is an important source of this zoonotic agent. The aim of this study was to determine the knowledge of consumers in Germany about Campylobacter, Salmonella and Toxoplasma and their transmissibility via meat. In addition, we investigated the level of knowledge between selected consumer groups and whether the results coincided with those of international studies.

Methods: We conducted a cross-sectional survey of 1008 consumers in Germany via an online panel to record, analyse and evaluate the state of knowledge about Campylobacter, Salmonella and Toxoplasma. The participants were selected according to age, gender and federal states to be representative of the German population.

Results: Overall, $68.3 \%$ of the respondents had never heard of Campylobacter, 20.2\% had heard of Campylobacter but did not know how to protect themselves, and only $11.5 \%$ knew how to protect themselves from Campylobacter infections. Slightly more than half (52.2\%) of the respondents who had at least heard of Campylobacter knew that Campylobacter was transmissible via meat. Knowledge increased significantly with age. Participants over 60 years old knew about Campylobacter almost three times as often as the 16- to 19-year-old comparison group (OR= 2.982). Consumers who had at least a secondary school certificate were almost twice as likely to know about Campylobacter as those who had no school certificate or a lower secondary school certificate $(O R=1.899)$. Participants who were not actors in the food chain were significantly less frequently informed about Campylobacter than were those who were actors in the food chain. Consumer knowledge of Toxoplasma was better than that of Campylobacter. Consumers have the most knowledge about Salmonella.

Conclusions: Consumers in Germany are predominantly poorly informed about Campylobacter and the transmission route via meat. General knowledge of Toxoplasma is better than that of Campylobacter. Among the three pathogens, consumers are best informed about Salmonella. This finding highlights the importance of making existing information materials more accessible to consumers in the future to increase their knowledge, with the objective of reducing the incidence of Campylobacter infections.
\end{abstract}

Keywords: Campylobacter, Salmonella, Toxoplasma, Public health, Online survey, Awareness

\footnotetext{
* Correspondence: roswitha.merle@fu-berlin.de

${ }^{1}$ Institute for Veterinary Epidemiology and Biostatistics, Freie Universität Berlin, Königsweg 67, 14163 Berlin, Germany

Full list of author information is available at the end of the article
}

(c) The Author(s). 2020 Open Access This article is licensed under a Creative Commons Attribution 4.0 International License, which permits use, sharing, adaptation, distribution and reproduction in any medium or format, as long as you give appropriate credit to the original author(s) and the source, provide a link to the Creative Commons licence, and indicate if changes were made. The images or other third party material in this article are included in the article's Creative Commons licence, unless indicated otherwise in a credit line to the material. If material is not included in the article's Creative Commons licence and your intended use is not permitted by statutory regulation or exceeds the permitted use, you will need to obtain permission directly from the copyright holder. To view a copy of this licence, visit http://creativecommons.org/licenses/by/4.0/ The Creative Commons Public Domain Dedication waiver (http://creativecommons.org/publicdomain/zero/1.0/) applies to the data made available in this article, unless otherwise stated in a credit line to the data. 


\section{Background}

Campylobacter, Salmonella and Toxoplasma are zoonotic agents that can be transmitted via food [1]. Foodborne infections occur in most countries worldwide, although with various levels of reported cases. Countries differ, for example, in that they either have compulsory and voluntary reporting systems. In addition, either case-related or aggregated data are made publicly available [2]. Germany is one of the countries stringent rules on food hygiene and a well-implemented public health system with regular testing of stool samples in suspected cases. With 69,414 confirmed cases in 2017 [3], enteritis caused by Campylobacter is the most common bacterial infection causing diarrhoeal disease reportable in Germany. In comparison, the 14,269 confirmed cases of salmonellosis are low. Nevertheless, it is, after campylobacter enteritis, the second-most common reportable bacterial gastrointestinal disease [3]. Seven cases of congenital human toxoplasmosis were confirmed in 2017. The recorded incidence of Campylobacter was 84 cases per 100,000 inhabitants in 2017. For salmonellosis, there were 17 cases per 100,000 inhabitants [3]. The average notification rate within the European Union was 64.8 cases of Campylobacter per 100, 000 inhabitants in 2017. The highest country-specific notification rates in 2017 were observed in the Czech Republic (230.0 cases per 100,000), Slovakia (127.8), Sweden (106.1) and Luxembourg (103.8). In 2017, the lowest rates were observed in Bulgaria, Cyprus, Latvia, Poland, Portugal and Romania ( $\leq 5.8$ per 100,000$)$ [2]. In New Zealand, the incidence of Campylobacter of 158.9 cases per 100,000 inhabitants in 2016 was almost twice as high as that in Germany [4]. Compared to Campylobacter, the reporting rate within the European Union indicates that there were 19.7 cases of salmonellosis per 100,000 inhabitants in the same year and 1.31 cases of toxoplasmosis per 100,000 live births [2]. An infection with Salmonella or Campylobacter can result in acute common unspecific symptoms such as diarrhoea, abdominal pain, fever and vomiting [3]. In addition to acute unspecific symptoms, complications such as Guillain-Barré syndrome and reactive arthritis can occur as long-term sequelae of Campylobacter [5]. Infection with Toxoplasma is usually subclinical in healthy adults, but an initial infection during pregnancy can result in severe damage, e.g., to the brain of the unborn child [3]. A common source of Campylobacter infection is poultry meat, especially broiler meat [2]. Beef and pork can also be considered sources, but red meat is far less likely to be contaminated with Campylobacter than poultry meat [6]. A common source of Salmonella infections are eggs and egg products, meat and meat product subcategories and bakery products [2]. The transmission of Toxoplasma may occur through insufficiently cooked contaminated meat or handling of infected cats [3].

According to different studies, the majority of consumers in Germany believe that food is $100 \%$ safe $[7,8]$.
Although 23\% of consumers in Germany are aware that Campylobacter may be present in food, only $9 \%$ are concerned about the possibility of acquiring foodborne campylobacteriosis [9]. In general, consumer awareness of specific pathogens has increased [10], but international studies have also indicated that consumers' knowledge about Campylobacter is predominantly poor [11-16]. Although consumers generally know that microorganisms such as Salmonella can be present in meat and may cause food-borne diseases $[17,18]$, it becomes apparent that many consumers are unaware that Campylobacter is explicitly transmitted via meat [16-19].

According to the European Food Safety Authority, between 20 and $30 \%$ of Campylobacter cases in humans can be attributed to the handling, preparation and consumption of chicken meat [20]. However, there is insufficient evidence to show how much knowledge consumers or certain consumer groups in Germany have about Campylobacter and whether they are aware that Campylobacter can be transmitted directly or indirectly via meat.

The aim of the study was therefore to assess the knowledge of consumers in Germany about Campylobacter and its transmission pathways and to compare this knowledge to that about Salmonella and Toxoplasma. Differences in knowledge between selected consumer groups were identified to better target information campaigns. In addition, the general knowledge of consumers on Campylobacter, Salmonella and Toxoplasma were compared. In our view, more knowledge about the pathways of infection at the consumer level is essential to improve public health.

\section{Methods}

Data collection and questionnaire development

To conduct this study, a questionnaire was designed comprising a total of 43 questions divided into five sections. The questionnaire focused not only on Campylobacter but also included other zoonotic pathogens transmissible via meat, such as Salmonella and Toxoplasma. For comparison purposes, pathogens such as the rabies virus and the human immunodeficiency virus, which are not transmissible to humans via meat, were also included. Questions covered the following topics: sociodemographic and socioeconomic factors; consumer knowledge of pathogens such as Campylobacter, Salmonella and Toxoplasma; involvement; and the influence of selected actors in the poultry meat food chain on poultry meat safety and quality from the consumer perspective. The participants of the study were registered consumers in an online access panel in Germany who were invited to participate in the online survey via an individual e-mail link. This link could only be used once for participation; thus, multiple participation sessions were excluded. The questionnaire was written in German, and an English translation is available in the 
supplements. The panel provider GapFish recommended surveying at least 1000 consumers in Germany to obtain a good demographic representation and ensure a low margin of error. GapFish is a company and the operator of a panel platform where participants are registered and can be selected according to personal data such as age, gender and occupation. The target group was the population aged 16 years and older. Only persons with German language skills could participate, which might have partly excluded first-generation immigrants. To ensure representativeness regarding age and geographical location, the study population was proportionally stratified according to federal state, gender and age group. Sampling was continued until all strata were complete. If a stratum was complete, further participation was refused. Ultimately, responses from 1008 consumers were included in the analysis. Data collection started on 11 August 2017 and was completed on 20 August 2017.

\section{Statistical analysis}

The evaluation of the data was conducted with IBM SPSS Statistics Version 24. The responses of 1008 consumers who had answered all questions completely were included in the statistical analysis. We did not have to remove any incomplete answers, as 1008 complete answers were submitted directly by the panel provider. Exceptions from completeness were made regarding questions on the level of education, primary residence, number of children in the household and household income after tax. There was an option for participants to indicate that they could not answer the question or did not want to answer it. If a participant selected one of these answer options, this answer was not considered in the univariable and multivariable analyses, thus reducing the item-specific sample size.

Descriptive statistics included frequency tables concerning questions about Salmonella, Campylobacter and Toxoplasma.

Univariable associations between categorical variables were analysed by cross-tabulation and chi-square statistics. If the number of cells with expected values below 5 was above 25\%, Fisher's exact test was used instead of the chi-square test. The level of significance was set to 0.05. Whenever possible, odds ratios (ORs) were calculated to compare the odds of a certain event in one group to those in other group. First, three different target variables were examined. In the first set of chisquare tests, the target variable was defined as the general level of knowledge of Campylobacter among consumers. The parameter values of these target variables were "Campylobacter is unknown" vs. "Campylobacter is known". The influence of various factors, such as age and gender, on the probability that the participant had heard of Campylobacter was investigated. In the second model, consumer knowledge of the transferability of Campylobacter via meat was used as the dependent variable. The parameter values of these target variables were "transferability is known" vs. "transferability is not known". These questions could only be answered by consumers who had already heard of Campylobacter. Here, the influence of various factors, such as age and gender, on the likelihood that the participant knew that Campylobacter could be transmitted to humans via meat was investigated. Third, it was investigated whether the different levels of consumer knowledge about possible protective measures against Campylobacter had an influence on the likelihood that consumers were aware of the transferability of Campylobacter via meat. The parameter values of knowledge were "Campylobacter is known, but it is unknown how to protect oneself" vs. "Campylobacter is known and how to protect oneself". Consumers who had never heard of Campylobacter before were not asked this question and therefore could not be included in the analysis. The latter test was also performed for Salmonella and Toxoplasma.

Categorical variables were analysed separately in the univariable chi-square tests and were then included in subsequent multivariable logistic regression models. This procedure was only conducted for the first two target variable analyses. The final models were identified through a manual backward selection process. In each step, the variable with the highest $p$-value was removed. After the removal of one variable, the change in the regression coefficients of the remaining variables as well as the change of model R-squared were investigated. If the changes were above $15 \%$, the removed variable was included again to control for confounding. The final models included the variables with $p$-values $<0.05$. Twoway interactions between explanatory variables were considered in the multivariable model and were removed, since all interactions turned out to be not statistically significant. Regression coefficients, $p$-values and ORs (including 95\% confidence intervals) are reported.

\section{Results}

General knowledge about campylobacter, Salmonella and toxoplasma

Overall, $68.3 \%$ (688/1008) of the respondents had never heard of Campylobacter. A total of 20.2\% (204/1008) had heard of Campylobacter but did not know how to protect themselves, while $11.5 \%$ said they knew how to protect themselves from Campylobacter. A total of $2.8 \%$ (28/1008) of respondents had never heard of Salmonella. A total of 19.9\% (201/1008) had heard of Salmonella but did not know how to protect themselves, while $77.3 \%$ (779/1008) said they had heard of Salmonella and knew how to protect themselves. Of all respondents, almost half $(48.3 \%)$ did not know about Toxoplasma. Almost $1 / 3$ 
(32.8\%) knew about Toxoplasma but did not know how to protect themselves, while $18.8 \%$ stated that they knew about both the infectious agent and how to protect themselves.

\section{General knowledge about Campylobacter from different consumer groups}

An overview of general knowledge about Campylobacter, Salmonella and Toxoplasma from different consumer groups is shown in Table 1.

A total of $67.2 \%(336 / 500)$ of the women and $69.3 \%$ $(352 / 508)$ of the men did not know about Campylobacter. A total of $20.6 \%(103 / 500)$ of women did not know how to protect themselves from infection; these women differed from those who had not heard of it. A total of $19.9 \%$ of men (101/508) did not know how to protect themselves from infection; these men also differed from those who had not heard of it. Approximately 12.2\% $(61 / 500)$ of women and $10.8 \%(55 / 508)$ of men knew how to protect themselves.

Of the young adults between 16 and 19 years of age, only $10.2 \%(18 / 176)$ knew about Campylobacter but did not know how to protect themselves, and 9.7\% (17/176) both knew about Campylobacter and knew how to protect themselves. Of the 20- to 39-year-old participants, 20.1\% (44/219) knew about Campylobacter but did not know how to protect themselves, while 11.0\% (24/219) said they knew how to protect themselves from infection. Of those consumers with no or a lower secondary school certificate, $12 \%(13 / 108)$ had already heard of Campylobacter, and 9.3\% (10/108) also knew how to protect themselves from infection. Of those who had at least a secondary school certificate, 21.4\% (188/878) knew about Campylobacter but did not know how to protect themselves, and $11.7 \%(103 / 878)$ knew how to protect themselves.

Of all respondents, $11.6 \%(117 / 1008)$ said they worked actively in the food chain. This included agricultural holdings, meat sales, slaughtering and processing, food monitoring and animal transport. Approximately half (64/117) of these respondents did not know about Campylobacter, 26.5\% (31/117) said they had heard of Campylobacter, and $18.8 \%(22 / 117)$ indicated that they knew how to protect themselves from Campylobacter. Of the participating veterinarians, $16.7 \%(2 / 12)$ did not know about Campylobacter, 33.3\% (4/12) knew about Campylobacter but did not know how to protect themselves against infection, and 50.0\% (6/12) knew how to protect themselves.

\section{General knowledge of Salmonella from different consumer groups}

Of the young adults between 16 and 19 years of age, $35.8 \%$ (63/176) knew about Salmonella but did not know how to protect themselves, and 55.1\% (97/176) knew about Salmonella and how to protect themselves. Of the $>60$-year-old participants, $13.6 \%$ (22/162) knew about Salmonella but did not know how to protect themselves, while $85.2 \%(138 / 162)$ said they knew how to protect themselves from infection.

Approximately $1 / 4$ (24.6\%) of low-income respondents (62/252) knew about Salmonella but did not know how to protect themselves, and $70.6 \%(178 / 252)$ of this group knew how to protect themselves from infection. Among consumers with high incomes, $18.8 \%$ (33/176) did not know how to protect themselves, while $80.7 \%$ from this group knew how to protect themselves. Of those consumers who were actors in the food chain, $6 \%$ did not know about Salmonella, while $72.6 \%$ knew how to protect themselves. Of consumers who were not actors in the food chain, 2.4\% were unaware of Salmonella. On the other hand, $77.9 \%$ of them knew how to protect themselves.

\section{General knowledge of Toxoplasma from different consumer groups}

Of the young adults between 16 and 19 years, 76.7\% (135/176) did not know about Toxoplasma. Of the adults between 20 and 39 years of age, 44.7\% (98/219) did not know about Toxoplasma. In all age groups, less than $25 \%$ know how to protect themselves from toxoplasmosis infection. Of the women, $43.0 \%$ did not know about Toxoplasma, and $53.5 \%$ did know about Toxoplasma. Almost $25 \%$ of female responders knew how to protect themselves from infection. The percentage for men was $14.4 \%$. Of the respondents with children $(162 / 337)$ and those without (315/654), almost the same number (48.1 and $48.2 \%$ ) did not know about toxoplasma. Approximately one-quarter of respondents with children (25.5\%) knew how to protect themselves from infection. Of those without children, $15.7 \%$ knew this information.

\section{Consumer knowledge about meat as a vector of Campylobacter, Salmonella and Toxoplasma}

Consumers who had at least indicated knowing about Campylobacter, Salmonella or Toxoplasma were asked if the respective pathogen was transmissible via meat. Slightly more than half $(52.2 \%)$ of respondents who had at least heard of Campylobacter (167/320) said that Campylobacter was transmissible via meat.

Of those consumers who did not know how to protect themselves against Campylobacter infection, 45.6\% (93/ 204) thought Campylobacter could be transmitted via meat. In comparison, $63.8 \%$ (74/116) of consumers who knew how to protect themselves against Campylobacter infection thought that Campylobacter could be transmitted via meat (Table 2). This difference was statistically significant $(\mathrm{OR}=2.1 ; p=0.002$, chi-square test $)$. 


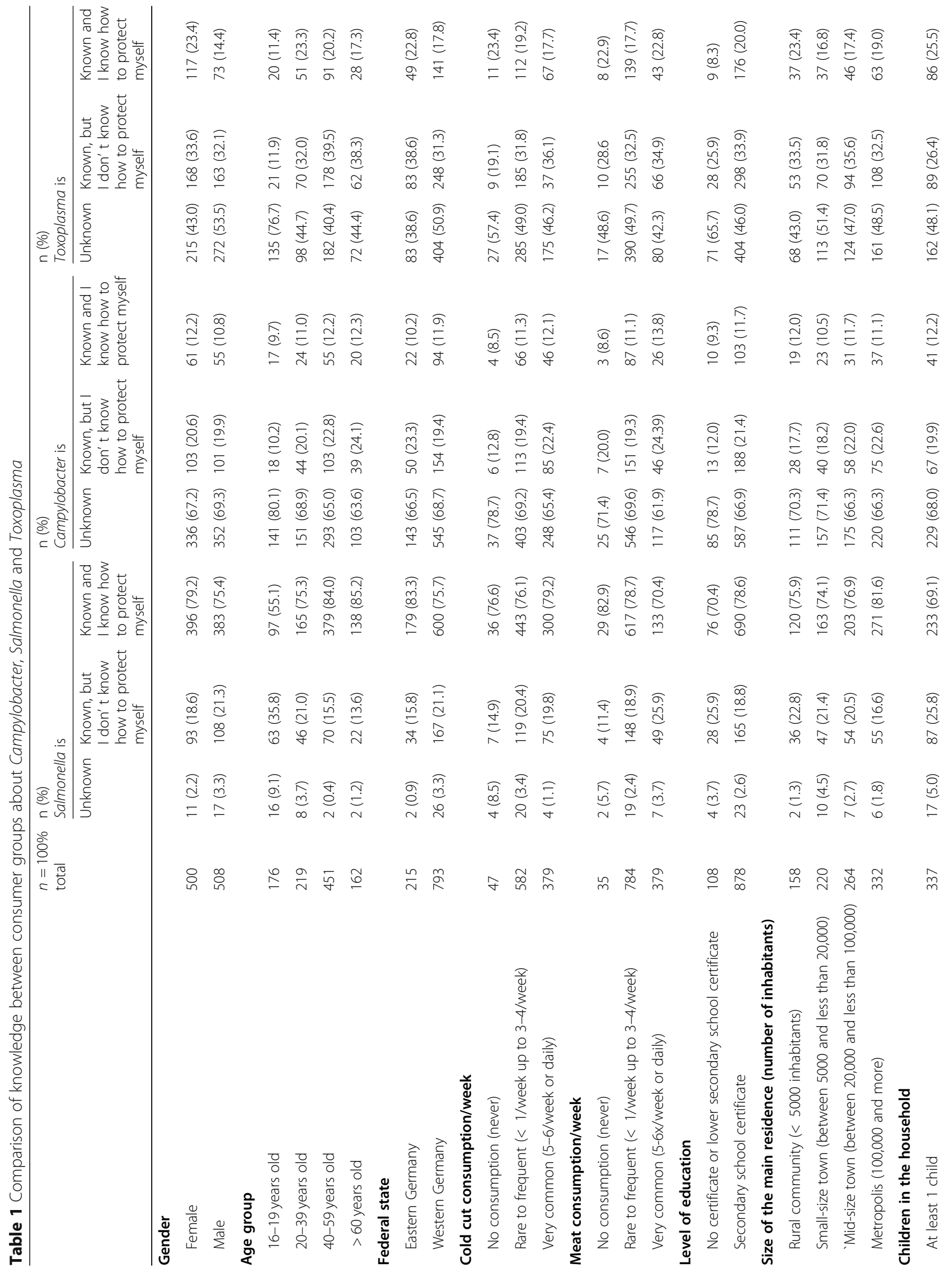




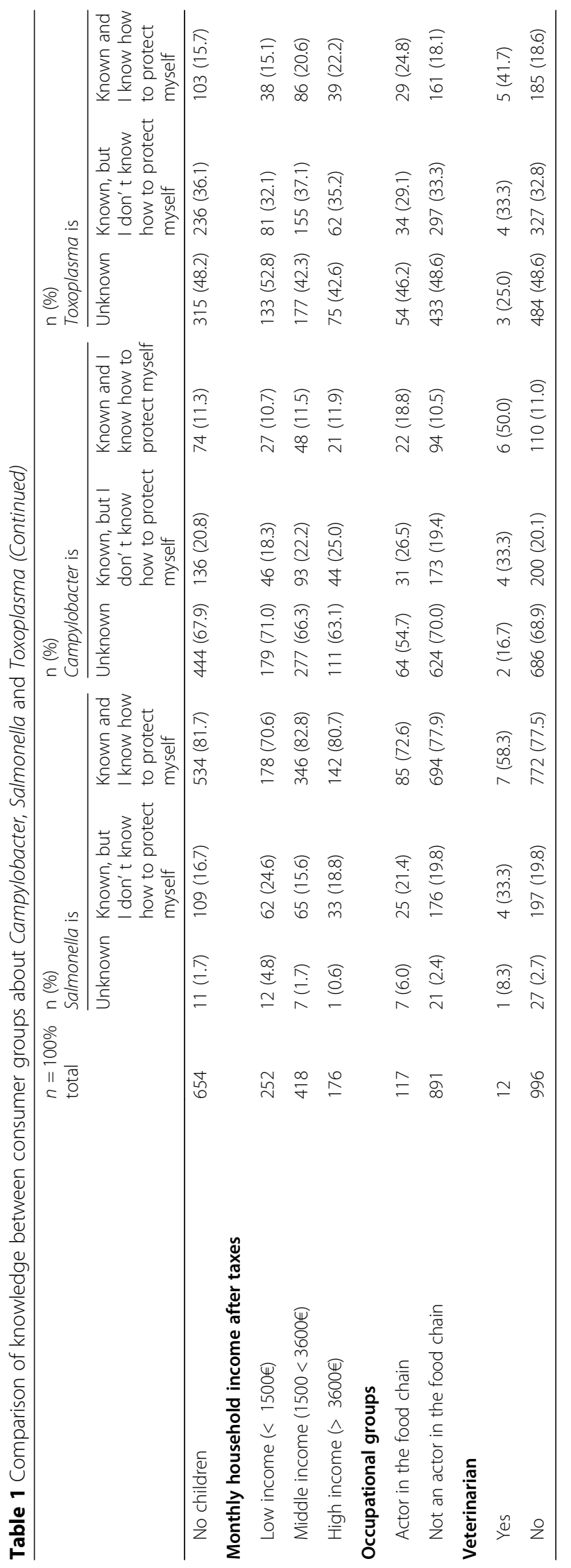


Table 2 General consumer knowledge about meat as a vector of Campylobacter based on a representative survey in Germany (2017)

\begin{tabular}{|c|c|c|c|c|c|c|}
\hline Consumer knowledge & $\mathrm{n}$ & $\begin{array}{l}\text { n (\%) } \\
\text { Campylobacter is } \\
\text { transmissible via meat }\end{array}$ & $\begin{array}{l}\mathrm{n}(\%) \\
\text { Campylobacter is not } \\
\text { transmissible via meat }\end{array}$ & $\begin{array}{l}X^{2} \text { test } \\
p \text {-value }\end{array}$ & OR & $95 \% \mathrm{Cl}$ \\
\hline I have heard of it, but I do not know how to protect myself. & 204 & $93(45.6)$ & $111(54.4)$ & 0.002 & 2.1 & $1.32-3.36$ \\
\hline I have heard about it, and I know how to protect myself. & 116 & $74(63.8)$ & $42(36.2)$ & & & \\
\hline Total & 320 & $167(52.2)$ & $153(47.8)$ & & & \\
\hline
\end{tabular}

Of those consumers who did not know how to protect themselves against Salmonella infection, 78.6 (158/201) thought that Salmonella could be transmitted via meat. In comparison, 88.7\% (691/779) of consumers who knew how to protect themselves against Salmonella infection thought that Salmonella could be transmitted via meat (Table 3). This difference was statistically significant $(\mathrm{OR}=2.1 ; p<0.001$, chi-square test).

Approximately half (50.7\%) of respondents who had at least heard of Toxoplasma (257/521) said that Toxoplasma was transmissible via meat. Of those consumers who did not know how to protect themselves against Toxoplasma infection, 40.8 (135/331) thought that Toxoplasma could be transmitted via meat. In comparison, $64.2 \%(122 / 190)$ of consumers who knew how to protect themselves against Toxoplasma infection thought that Toxoplasma could be transmitted via meat (Table 4). This difference was statistically significant $(\mathrm{OR}=2.6$; $p<0.001$, chi-square test).

\section{Investigation of knowledge about Campylobacter within different consumer groups}

The level of knowledge varied significantly between different consumer groups concerning Campylobacter. The chi-square test showed significant differences in the levels of knowledge between the different age groups $(p=0.002)$, education levels $(p=0.013)$, and occupational groups (i.e., veterinarians and non-veterinarians $(p<0.001))$, as well as between participants who were active in the food chain and those who did not work in the food chain $(p=0.001)$ (Table 5). All other variables tested, such as gender, location of main residence, state affiliation, frequency of cold cut and meat consumption, number of children in the household and household income after taxes, were not statistically significantly associated with the level of knowledge about Campylobacter at the univariable level (Table 5). Selected influencing factors were included in the multivariable logistic regression model. In addition to the variables that were statistically significant in the univariable analysis, no further relevant potential risk factors or confounders were identified for inclusion in the multivariable model. In the final logistic regression model, the results of the univariable tests could be confirmed. Thus, the knowledge about Campylobacter differed significantly between different age groups $(p<0.001)$, educational levels $(p=$ $0.010)$ and selected professional groups, such as veterinarians and non-veterinarians $(p=0.004)$ and actors and non-actors in the food chain $(p=0.007)$. Knowledge increased significantly with age: 20 - to 39 -year-old participants were approximately twice as likely to know about Campylobacter as 16- to 19-year-old participants (OR = 2.021). The 40- to 59-year-old participants were slightly more than 2.5 times more likely to know about Campylobacter than the comparison group of 16- to 19-yearolds $(\mathrm{OR}=2.664)$. The participants older than 60 years old were almost 3 times more likely to know about Campylobacter than the comparison group $(\mathrm{OR}=2.982)$. We could also show that consumers with a higher level of education were significantly more frequently informed than those with a lower level of education. Consumers who had at least a secondary school certificate were almost twice as likely to know about Campylobacter as those who had no school certificate or a lower secondary school certificate $(\mathrm{OR}=1.899)$. Participants who were not actors in the food chain were significantly less frequently informed about Campylobacter than those in the food chain. This also applies to non-veterinarians in comparison to veterinarians.

\section{Knowledge differences about meat as a vector of Campylobacter within different consumer groups}

In the univariable data analyses that focused on consumer knowledge of the transferability of Campylobacter via meat as the target variable, we could show a statistically significant effect of age $(p=0.042)$. All other

Table 3 General consumer knowledge about meat as a vector of Salmonella based on a representative survey in Germany (2017)

\begin{tabular}{|c|c|c|c|c|c|c|}
\hline Consumer knowledge & $\mathrm{n}$ & $\begin{array}{l}\mathrm{n}(\%) \\
\text { Salmonella is } \\
\text { transmissible via meat }\end{array}$ & $\begin{array}{l}\mathrm{n}(\%) \\
\text { Salmonella is not } \\
\text { transmissible via meat }\end{array}$ & $\begin{array}{l}X^{2} \text { test } \\
p \text {-value }\end{array}$ & OR & $95 \% \mathrm{Cl}$ \\
\hline I have heard of it, but I do not know how to protect myself. & 201 & $158(78.6)$ & $43(21.4)$ & \multirow[t]{3}{*}{$<0.001$} & \multirow[t]{3}{*}{2.1} & \multirow[t]{3}{*}{$1.43-3.20$} \\
\hline I have heard about it, and I know how to protect myself. & 779 & $691(88.7)$ & $88(11.3)$ & & & \\
\hline Total & 980 & $849(86.6)$ & $131(13.4)$ & & & \\
\hline
\end{tabular}


Table 4 General consumer knowledge about meat as a vector of Toxoplasma based on a representative survey in Germany (2017)

\begin{tabular}{|c|c|c|c|c|c|c|}
\hline Consumer knowledge & $n$ & $\begin{array}{l}\mathrm{n}(\%) \\
\text { Toxoplasma is transmissible } \\
\text { via meat }\end{array}$ & $\begin{array}{l}\mathrm{n}(\%) \\
\text { Toxoplasma is not transmissible } \\
\text { via meat }\end{array}$ & $\begin{array}{l}x^{2} \text { test } \\
p \text {-value }\end{array}$ & OR & $95 \% \mathrm{Cl}$ \\
\hline $\begin{array}{l}\text { I have heard of it, but I do not know how to } \\
\text { protect myself. }\end{array}$ & 331 & $135(40.8)$ & $196(59.2)$ & $<0.001$ & 2.6 & $1.80-3.77$ \\
\hline $\begin{array}{l}\text { I have heard about it, and I know how to protect } \\
\text { myself. }\end{array}$ & 190 & $122(64.2)$ & $68(35.8)$ & & & \\
\hline Total & 521 & $257(50.7)$ & $264(49.3)$ & & & \\
\hline
\end{tabular}

variables examined did not show significant associations (Table 6). Only participants who knew about Campylobacter $(n=320)$ were included in this analysis. The logistic regression confirmed that only age group was statistically associated with consumer knowledge of Campylobacter transmissibility via meat $(p=0.044)$, although pairwise comparisons among age groups did not reveal significant differences (Table 7).

\section{Knowledge differences about meat as a vector of Campylobacter, Salmonella and Toxoplasma between consumers with different levels of knowledge about possible protective measures against these pathogens} (Tables 2, 3 and 4)

The chi-square test proved a significant difference in knowledge about the transferability of Campylobacter via meat between consumers with different levels of knowledge about possible protective measures against Campylobacter $(p=0.002)$. Those who knew how to protect themselves from Campylobacter infection were approximately twice as likely to know that Campylobacter was transmitted via meat as those who knew about Campylobacter but did not know how to protect themselves $(\mathrm{OR}=2.103)$.

With regard to Salmonella, the results indicated that there was a significant difference in knowledge about the transmissibility of Salmonella via meat between consumers with different consumer knowledge about possible protective measures against Salmonella $(p<0.001)$. Those who knew how to protect themselves against Salmonella infection knew about twice as often that Salmonella was transmitted via meat as those who knew about Salmonella but did not know how to protect themselves $(\mathrm{OR}=2.1)$.

With regard to Toxoplasma, it was shown that there was a significant difference in knowledge about the transferability of Toxoplasma via meat between consumers with different levels of knowledge about possible protective measures against Toxoplasma $(p<0.001)$. Those who knew how to protect themselves against Toxoplasma infection knew approximately 2.5 times more often that Toxoplasma was transmitted via meat than those who knew about Toxoplasma but did not know how to protect themselves $(\mathrm{OR}=2.6)$.

\section{Discussion}

Campylobacteriosis was the most frequently reported zoonosis throughout the European Union in 2017, and salmonellosis was the second-most common zoonosis to be reported in the European Union [2]. In addition to Europe, the number of cases of campylobacteriosis has also increased in North America and Australia [21]. The significant increase in the number of cases from below 55,000 in 2001 to more than 70,000 in 2016 in Germany highlights the importance of raising consumer awareness of Campylobacter. One reason for the increased case numbers could be that human consumption of poultry meat in Germany increased from $10.92 \mathrm{~kg} /$ head in 2001 to $13.19 \mathrm{~kg} / \mathrm{head}$ in 2018 [22], and consumers therefore come into contact with Campylobacter more frequently. Another reason for the increasing case numbers, especially in the summer months from June to September, could be the increased ambient temperature. Yun and colleagues [23] showed that the increase in ambient temperature is positively associated with the occurrence of Campylobacter. Although the incidences of salmonellosis decreased from 2001 to 2016 in Germany, in 2018, the number of infections was higher than in 2016 [24]. This shows that the success of activities to reduce the incidence cannot be taken for granted. The incidence of clinical toxoplasmosis ranged from 6 to 23 cases in the years 2002-2018 [24] and thus remains well below the incidence of Salmonella and Campylobacter.

Since this survey was conducted by a commercial online survey company and included target panels with a stratified sample, the survey could be conducted with little effort in a short amount of time. The number of necessary participants was quickly reached, and timeconsuming recruitment was not necessary. In addition, the acceptance among the participants was high, as they consciously decided to be participants in a panel, and the questionnaire could be answered online at any time of day and at any place. Data input and transmission were performed automatically so that transmission errors could be minimized. However, this did not insulate the study from forms of bias that are characteristic of online surveys. First, not all participant groups may be available online. In the event of queries, assistance may not be possible. In addition, the environment cannot be 


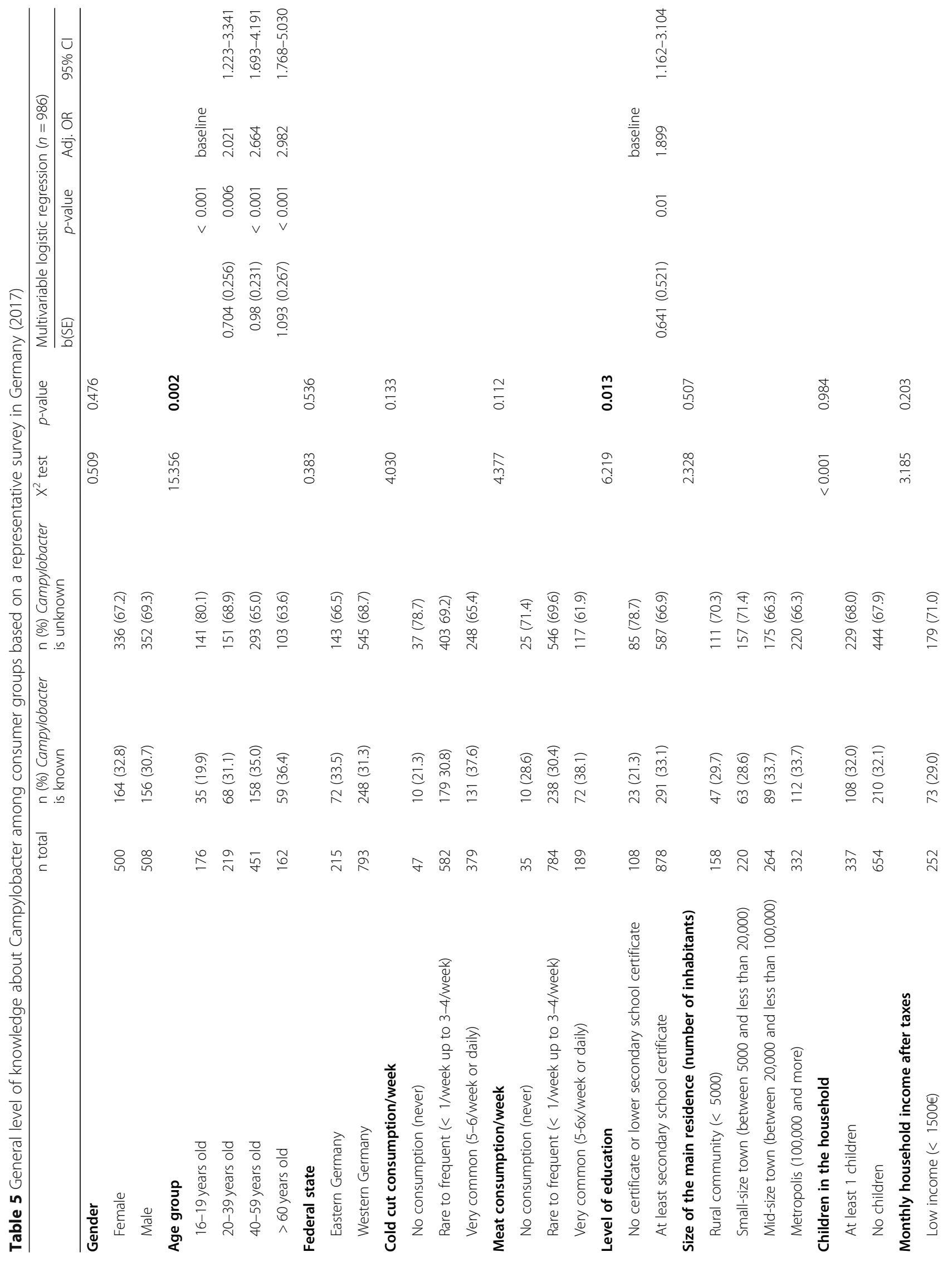




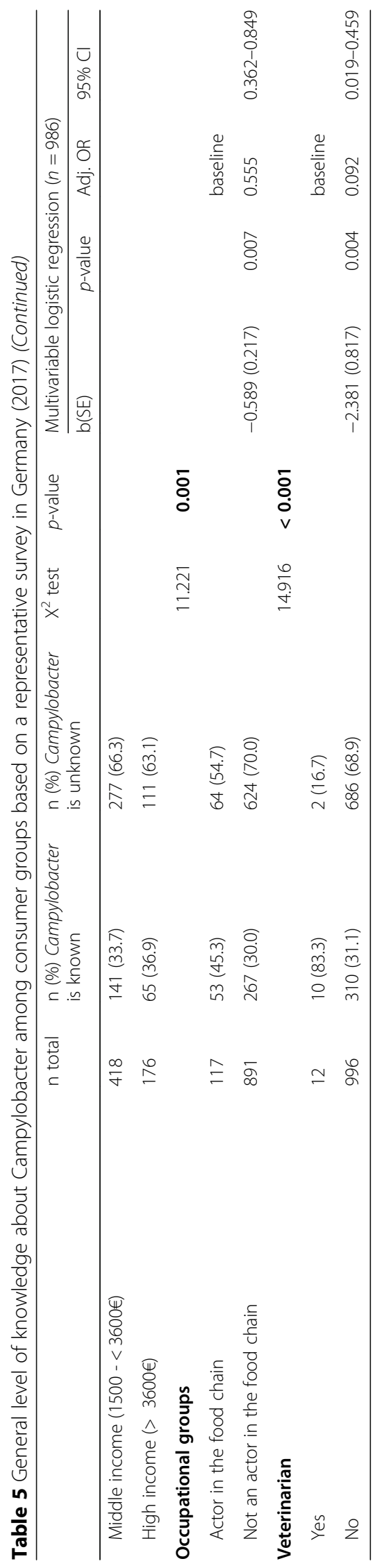


Table 6 Knowledge of consumer groups about the transmissibility of Campylobacter via meat based on a representative survey in Germany (2017). Included were participants who knew about Campylobacter $(n=320)$

\begin{tabular}{|c|c|c|c|c|}
\hline & $\begin{array}{l}\mathrm{n} \\
\text { total }\end{array}$ & $\begin{array}{l}\mathrm{n}(\%) \\
\text { Transferability is known }\end{array}$ & $\begin{array}{l}\mathrm{n}(\%) \\
\text { Transferability is unknown }\end{array}$ & $\begin{array}{l}X^{2} \text {-test } \\
p \text {-value }\end{array}$ \\
\hline Gender & & & & 0.926 \\
\hline Female & 164 & $86(52.4)$ & $78(47.6)$ & \\
\hline Male & 156 & $81(51.9)$ & 75 (48.1) & \\
\hline
\end{tabular}

\section{Age group}

$$
\begin{aligned}
& \text { 16-19years old } \\
& \text { 20-39years old } \\
& \text { 40-59 years old } \\
& >60 \text { years old }
\end{aligned}
$$

Federal state

$$
\text { Eastern Germany }
$$$$
\text { Western Germany }
$$

\section{Cold cut consumption/week}

No consumption (never)

Rare to frequent ( $<1 /$ week up to 3-4/week)

Very common (5-6/week or daily)

\section{Meat consumption/week}

No consumption (never)

Rare to frequent ( $<1 /$ week up to 3-4/week)

Very common (5-6x/week or daily)

\section{Level of education}

No certificate or lower secondary school certificate

At least secondary school certificate

\section{Size of the main residence}

Rural community (< 5000 inhabitants)

Small-size town (5000 - <20,000 inhabitants)

Mid-size town (20,000 - < 100,000 inhabitants)

Metropolis (100,000 inhabitants and more)

\section{Children in the household}

At least 1 child

No children

\section{Monthly household income after taxes}

Low income (< 1500€)

Middle income $(1500 €$ to $<3600 €)$

High income (> 3600€)

\section{Occupational groups}

Actor in the food chain

Not an actor in the food chain

Veterinarian

\section{5}

68

158

59

72

248

\section{0}

179

131

$$
11(47.8)
$$$$
155(53.3)
$$

$$
16 \text { (45.7) }
$$$$
34 \text { (50.0) }
$$$$
94 \text { (59.5) }
$$$$
23(39.0)
$$

40 (55.6)

$127(51.2)$

$8(80.0)$

86 (48.0)

$73(55.7)$

$7(70.0)$

$122(51.3)$

$38(52.8)$

$26(55.3)$

$$
34 \text { (54.0) }
$$$$
41(46.1)
$$$$
63 \text { (56.3) }
$$

19 (54.3)

$34(50.0)$

64 (40.5)

$36(61.0)$

$32(44.4)$

$121(48.8)$

2(20.0)

93 (52.0)

58 (44.3)

$136(46.7)$

49 (43.8)

97 (46.2) 
Table 7 Differences by age group in the knowledge that Campylobacter is transmissible via meat

\begin{tabular}{lllll}
\hline Logistic regression $(n=320)$ & & & \\
\hline & $b(S E)$ & $p$-value & OR & $95 \% \mathrm{Cl}$ \\
\hline 16-19 years old & & $\mathbf{0 . 0 4 4}$ & & \\
20-39years old & $0.172(0,417)$ & 0.680 & 1.188 & $0.524-2.689$ \\
40-59 years old & $0.556(0,376)$ & 0.139 & 1.744 & $0.835-3.645$ \\
> 60 years old & $-0.276(0,432)$ & 0.522 & 0.759 & $0.326-1.768$ \\
\hline
\end{tabular}

controlled during the survey. The presence of third parties cannot be ruled out, nor can the presence of other media, e.g., to provide assistance, be excluded [25]. Answering individual questionnaires by using automated answer scripts is theoretically possible but rather unlikely. The survey is not open to the public, and each person receives an individual e-mail link that can only be used once. Although there is no $100 \%$ guarantee, the panel provider takes as much care as possible to prevent automated answers.

Our results showed that the proportion of participants who did not know about Campylobacter at all was $68.3 \%$. This corresponds with the results of another study among consumers from Germany, in which $75 \%$ of the respondents did not know that Campylobacter occurs in food [9]. Publications from other European and non-European countries also show that consumers' knowledge of Campylobacter is predominantly poor. A total of $83.3 \%$ of Slovenian consumers did not know about Campylobacter [19]. In an Australian study, only $8 \%$ of respondents knew about Campylobacter [16]. A total of $22 \%$ of respondents in an Austrian study [14] and $16 \%$ of respondents in a U.S. study [13] had already heard of Campylobacter. In the U.S., consumer knowledge seems to have increased in recent years, since in an earlier study, only $7 \%$ of the participants had heard of Campylobacter [15].

Our results also showed that most consumers in Germany (>97\%) have heard of Salmonella at least once before. This corresponds with the results of another study among consumers from Germany, in which $96 \%$ of consumers had already heard of Salmonella in food [26]. In another study with an open question about pathogenic germs in food, only slightly more than half $(58.3 \% ; n=420)$ of the respondents mentioned Salmonella [27]. Publications from other European and nonEuropean countries also showed that consumer knowledge of Salmonella is generally good. In Austria, 98\% of consumers knew about Salmonella [14]. In Ireland, 92.9\% of respondents have already heard of Salmonella [18]. In the Netherlands, a study found that $97.4 \%$ of respondents said they knew that they could be infected with Salmonella from contaminated foods [28]. In two U.S. studies, more than $90 \%$ of consumers had already heard of Salmonella [13, 15]. In comparison to Salmonella and Campylobacter, our results showed that the general knowledge about Toxoplasma was almost equally divided among consumers. Forty-eight percent had never heard of the pathogen, and $51.7 \%$ had at least heard of Toxoplasma. In a study from Poland in which 565 pregnant women participated, 439 (94.4\%) of the respondents were aware of toxoplasmosis. A total of $77.4 \%$ knew it was a zoonosis [29]. A U.S. study showed that $48 \%$ of pregnant women had heard or seen information about toxoplasmosis [30]. A survey of pregnant and postpartum women in Brazil showed that only $27.8 \%$ knew that the disease existed. Most of them (72.2\%) had never heard of toxoplasmosis [31]. In a study from Zimbabwe, only $4 \%$ of 49 respondents knew that toxoplasmosis was a zoonosis that could be transmitted via cats [32]. Overall, there appear to be fewer consumer surveys than on Campylobacter and Salmonella. This may be because clinical symptoms usually do not occur except in pregnant women. In addition, the overall case numbers are significantly lower than those for Campylobacter and Salmonella in Germany as well as throughout the EU [33].

Our study showed that meat was not sufficiently known as the main vector of Campylobacter. Only half (52.2\%) of those who knew about Campylobacter ( $n=$ 320) knew that it could be transmitted to humans via meat. Although 116 consumers indicated that they knew how they could protect themselves, $36.2 \%$ (42/116) did not know that transmission occurs via meat. In general, consumers are aware that food-borne infections are often associated with chicken meat [34, 35], but an international comparison also shows that consumers do not know that meat is a vector of Campylobacter. An Australian study showed that only $9 \%$ of consumers associate Campylobacter with chicken and poultry [16]. In a U.S. study, only $0.4 \%$ of respondents could name a Campylobacter vector [36]. In Slovenia, only $18 \%$ of respondents knew how often Campylobacter was present on poultry meat in retail outlets [19]. A study from Switzerland showed a high level of general knowledge about pathogenic bacteria in poultry meat, but pathogenic bacteria are perceived as the least threatening in comparison to other potential food risks, such as the intake of too many calories, an unbalanced diet, hormone residues in meat or allergies [37]. In New Zealand, only $15 \%$ of respondents knew that a very high proportion of fresh chicken is contaminated with Campylobacter [11]. In a UK study, $24 \%$ of respondents had heard that Campylobacter can cause foodborne infection [12].

Our study also showed that meat was predominantly known as a vector of Salmonella. Only $13.4 \%$ of all respondents (131/980) who knew about Salmonella said they did not know that these pathogens could be transmitted to humans via meat. Nevertheless, it was found 
that some consumers misjudged their knowledge. Of those who said they knew how to protect themselves, $11.3 \%$ (88/779) did not know that Salmonella was transmissible via meat. An international comparison shows that many consumers are aware that meat can be a source of Salmonella transmission. A survey of students at the University of Maine showed that slightly more than half of those surveyed (57.3\%) were aware of an association between Salmonella and raw chicken [38]. Murray and Glass-Kaastra [34] showed that the majority of respondents are aware of the risks of foodborne illness associated with chickens, and the majority are aware that chickens that are not fully cooked can be a cause of foodborne illness. A study in Mexico showed that fresh meat is the most commonly considered sources of salmonellosis compared to other food categories, such as "fruits and vegetables" or "dairy products" [39]. In an Italian study, on the other hand, the awareness of Salmonella transmission was not particularly high. Only approximately $1 / 4$ of the respondents were aware of food vehicles for the transmission of Salmonella [40]. In Ireland, a study showed that of those who knew about Salmonella, only $23.1 \%$ knew that Salmonella can be transmitted via poultry. Only $4.7 \%$ knew that Salmonella could be transmitted via pork. The most frequently mentioned possible vectors that were correct were eggs (44\%) [18].

In our study, $50.7 \%$ knew that Toxoplasma could be transmitted via meat. Thus, we can conclude that consumers know more about the transmissibility of Toxoplasma via meat than about the transmissibility of Campylobacter via meat. A U.S. study showed that only $30 \%$ of pregnant women were aware that Toxoplasma may be found in raw or undercooked meat [30]. Another U.S. showed that only $24 \%$ of the respondents knew that Toxoplasma can be transmitted via food [13]. In a study from Poland that included only pregnant women, $46.7 \%$ knew that raw or uncooked meat was a route of transmission [29]. Nevertheless, it is also evident that significantly fewer consumers (16\%) know that Campylobacter can be transmitted via food. Again, most consumers (93\%) know that Salmonella can be transmitted via food [13].

Since the consumption of meat is known to be the main cause of Campylobacter infection, a reduction in meat consumption could lead to a reduced incidence of Campylobacter food-borne infections. A general reduction in meat consumption would also have the advantage of a lower number of Salmonella and Toxoplasma infections, although consumer knowledge of these pathogens is higher. Clinically manifest diseases or even deaths associated with the consumption of meat, and therefore secondary health care costs, may be reduced if knowledge about foodborne diseases were more widespread. Switching to a vegetarian diet would also reduce infection with these pathogens, as meat is the most common source of foodborne infections. A complete reduction in incidence is not possible because Campylobacter is also transmissible through raw milk [3] and Salmonella through eggs [33].

In addition, only $11.5 \%$ of the participants in our study who had heard of at least Campylobacter $(n=320)$ knew how to protect themselves from Campylobacter infection. Thus, it is not sufficient only to increase the level of knowledge about Campylobacter. In Germany, there are still too many consumers who do not wash their hands or the cutting board after preparing raw meat [41]. This result seems contradictory at first, since a survey of the German Federal Institute for Risk Assessment shows that $90 \%$ of the respondents indicated that they know how to protect themselves against pathogenic bacteria in their own household. At the same time, this survey also shows that only a minority of $9 \%$ of German consumers believe that compliance with kitchen hygiene serves as a protective measure against bacteria [42]. International comparative studies show that consumers are well aware of good hygiene practices and that many consumers are familiar with hygiene measures, such as washing their hands after handling raw meat $[43,44]$. One reason for the nevertheless increasing incidence of foodborne infections in general could be that consumers do not wash their hands properly, and cross-contamination still occurs [45]. Health policy has long recognized that insufficient consumer awareness of Campylobacter is a problem, and scientific institutions have already compiled comprehensive information for consumers. However, although much information about Campylobacter and protection against infection is available at the national and international levels [46-49], our results suggest that the available information does not reach consumers. Consumers must actively search for available information material. Increased media attention could increase consumer awareness and vigilance in food handling [44]. The general lack of dramatic outbreak situations for Campylobacter explains why media attention is rather weak. The total number of Campylobacter outbreaks is much lower than that of Salmonella infections. The number of people who need hospital treatment due to clinical symptoms is much lower for Campylobacter than for Salmonella [33]. Regarding Campylobacter, 3\% of the patients need to be hospitalized, whereas this is necessary for $19.5 \%$ of Salmonella patients. In addition, low mortality has occurred in those with Campylobacter infections than in those with Salmonella infections [33].

Providing a label with appropriate handling instructions or warning signs indicating the Campylobacter risk could increase consumer awareness. This is confirmed, for example, by the results of other consumer surveys $[11,50]$. Approximately $80 \%$ of consumers in Germany 
have the opinion that it is not easy to discern whether a foodstuff can cause health problems if handled incorrectly [51]. According to the results of the Deutsche Landwirtschafts-Gesellschaft e.V [52]., which informs consumers about the quality of food (among other things) and conducts studies on the food industry, consumers in Germany think that such information on the packaging would be very useful. It is therefore necessary to identify methods to ensure that the available information materials reach consumers.

According to the Robert Koch Institute case numbers of Campylobacter, men are generally more exposed to infections than women [53]. However, in our study, we could not show that men were significantly less informed about Campylobacter than women. Therefore, we could not confirm any association between the level of knowledge of men and women and the incidence of the disease. This is also coincident with results from Lin et al. [15]. Women are significantly more interested in food safety issues than men, although there is no statistically significant relationship between gender and food safety knowledge [35]. This is confirmed in other studies $[54,55]$. Rossvoll et al. [56] came to a different conclusion: according to their results, men seem to know less about food safety than women and have more knowledge deficits in hygiene practices. It has also been shown that there are knowledge differences between men and women regarding the fact that microorganisms are the cause of food-borne infections [57]. Tomaszewska et al. [58] found different results in two different countries in their study: while in Poland, women showed a slightly higher level of knowledge about food hygiene than men, this significant gender difference in knowledge could not be established in Thailand.

Younger consumers are less interested in food safety issues than older consumers are [35]. This could explain why the knowledge about Campylobacter in our study differed statistically significant by age group, and young adults $<20$ years were the least informed. A possible explanation would be that approximately $80 \%$ of the female and over $80 \%$ of the male 19-year-olds still live in their parents' households [59]. In addition, $30 \%$ of individuals under 19 years old in Germany generally do not prepare their meals themselves, whereas those over 60 years old cook more often than the average person [60]. Children may not be as concerned about food safety and the transmission of pathogens through food because the parents often prepare the food for the children even if they are already grown up. In comparison to our study, Lin et al. [15] found that the age groups investigated in their study did not differ significantly with regard to Campylobacter knowledge. Similarly, Stratev et al. [54] could not establish a significant relationship between age and knowledge of food safety.
We found that consumers with a higher education level were significantly more informed about Campylobacter than those with lower education. Similar results were also shown in a U.S. study. Consumers with at least some college education are more likely to have heard of Campylobacter than those with less education were [15]. Further study results also suggest that the more educated consumers are, the better their knowledge of food safety [55, 61]. However, Zorba and Kaptan [35] found no significant correlation between educational level and food safety issues.

Comparable to our study, other studies have not found that consumers with higher household incomes after taxes are significantly better informed about Campylobacter than are consumers with lower incomes [15]. However, there are also studies showing that safe food handling is more prevalent among consumers with higher incomes [62].

We could confirm that actors in the food chain, and veterinarians in particular, are better informed about Campylobacter than are those who are not or have not been active in this sector. We have assumed that there is a certain level of knowledge about pathogens that occur in the immediate occupational sector. A study from Ontario that surveyed actors and veterinarians involved in pig production showed corresponding results. More veterinarians were familiar with Campylobacter and other microbial hazards than were individuals in other occupational groups. One explanation seems to be that veterinarians are informed about pathogens through their education and that knowledge about zoonosis is an important component [63]. However, our finding that more than half of the actors in the food chain $(54.7 \%)$ did not know about Campylobacter at all was very interesting. One survey showed significant gaps in the knowledge of Campylobacter among broiler chicken producers. While $82.4 \%$ of those surveyed know that Salmonella could be transmitted to humans via contaminated chicken meat, only $21 \%$ of chicken meat producers knew that the same applies to Campylobacter [64]. A survey of pork producers showed that knowledge of Campylobacter is also low among this group. Only $12.8 \%$ of respondents knew that Campylobacter could infect humans [65]. There also seem to be gaps in the knowledge of food workers in meat processing plants. While there is a high level of knowledge of general protective measures, most workers are not well aware of specific diseases or pathogens that could be transmitted through food [66]. A U.S. study from Pennsylvania also showed gaps in the knowledge of poultry product vendors about pathogens and crosscontamination during poultry processing [67].

Although there are statistically significant differences in the level of knowledge by age group, educational level, occupational group and status as a veterinarian, there 
must be other factors that significantly influence the level of knowledge.

\section{Conclusions}

Campylobacter, despite its high incidence in Germany, is largely unknown to consumers. Since elimination from poultry farms and within the poultry production chain is not foreseeable at present, one focus of infection prevention and educational work must be to sensitize consumers. Based on the results of our study, it can be concluded that the risk of a foodborne infection by Campylobacter may be underestimated or not perceived as such, and consumers' assessments do not seem to correspond to scientific findings. Even if certain consumer groups appear to be better informed than others, it is evident, nationally and internationally, that consumer knowledge about Campylobacter and their transmission routes must be increased to reduce the high annual incidence of Campylobacter infections. However, the findings seem to be different for Salmonella. Knowledge about Salmonella is much better, and the number of cases has decreased since the beginning of this century. Although knowledge about toxoplasmosis is not as high as knowledge about Salmonella, the persons for whom an infection is clinically relevant seem to be well informed. Overall, it is a great challenge to accurately target information on the safe handling of food to consumers. There is no lack of information materials per se, and educational campaigns take place in the real world as well as in social media. Consumers must become aware that they have a large part of the responsibility themselves. It must be made clear that purchased food might contain pathogenic microorganisms and that it is up to consumers to safely handle food or prepare food to kill microorganisms before consumption. In addition to heating raw meat sufficiently, consumers must comply with general hygiene measures, such as washing hands, and reduce cross-contamination by using various kitchen utensils. Finally, the risk of infection can be reduced by reducing meat consumption. Educating consumers about the responsibilities of the actors in the food chain, including themselves, could help to reduce foodborne infections. To provide information materials on the abovementioned risks and protective measures against food-borne infections to consumers, one possibility would be to disseminate information via social media. This would enable a large number of consumers to be reached, as such information would be passed on to friends and acquaintances by the consumers themselves. The development of an innovative phone app would also be conceivable, since a large part of the population is now reached through this medium; gaps in knowledge could be conveyed through this phone app. Appropriate marketing at the point of sale, in newspapers, in social media and on TV would be useful here, so that as many consumers as possible are made aware of such an app.

\section{Abbreviations}

OR: Odds ratio; US: United States; e.g.: Example given

\section{Acknowledgements}

We thank the panel provider GapFish for the execution of the study and all participants in the study.

\section{Authors' contributions}

$\mathrm{KAH}$ is the first author. $\mathrm{KAH}$ and MGD were involved in the conception and design of the study and the questionnaire. $\mathrm{KAH}$ analysed the data and drafted the manuscript. RM und TA were involved in the data analysis. All authors were involved in the revision of draft manuscripts and the approval of the final manuscript.

\section{Funding}

The study was partly funded by pangea labs $\mathrm{GmbH}$. This work was partly funded by the German Federal Ministry of Education and Research under project number 01Kl1725A as part of the Research Network on Zoonotic Infectious Diseases. pangea labs $\mathrm{GmbH}$ provided the software to prepare the online survey, including the layout. The funding bodies were not involved in the design of the study; the collection, analysis and interpretation of the data; or the preparation of the manuscript.

Availability of data and materials

Raw data of the study are available upon request to the corresponding author.

\section{Ethics approval and consent to participate}

According to the guidelines for online surveys of market and social research associations in Germany, formal ethical approval was not required. This guideline states that the scientific approach of the survey, the informed consent to participate, the anonymization of the participants and the strict separation of scientific from nonscientific activities have to be granted [68]. GapFish guarantees that all requirements are fulfilled. Participants have longterm agreements with GapFish and have given written consent to participate.

\section{Consent for publication}

Not applicable.

\section{Competing interests}

The authors declare that they have no competing interests.

\section{Author details}

${ }^{1}$ Institute for Veterinary Epidemiology and Biostatistics, Freie Universität Berlin, Königsweg 67, 14163 Berlin, Germany. ${ }^{2}$ Institute of Food Safety and Food Hygiene, Freie Universität Berlin, Königsweg 67 and 69, 14163 Berlin, Germany.

Received: 28 September 2019 Accepted: 6 March 2020 Published online: 16 March 2020

\section{References}

1. Robert Koch Institut. Infektionsepidemiologisches Jahrbuch meldepflichtiger Krankheiten für 2014, Berlin. 2015. https://www.rki.de/DE/Content/Infekt/ Jahrbuch/Jahrbuch_2014.pdf?_blob=publicationFile. Accessed 26 Aug 2019

2. European Food Safety Authority. The European Union summary report on trends and sources of zoonoses, zoonotic agents and food-borne outbreaks in 2017. 2018. https://efsa.onlinelibrary.wiley.com/doi/epdf/10.2903/j.efsa.201 8.5500. Accessed 28 Aug 2019.

3. Robert Koch Institut. In hrbuch meldepflichtiger Krankheiten für 2017. Berlin2018. https://www.rki.de/DE/Content/Infekt/Jahrbuch/Jahrbuch_2017. pdf?_blob=publicationFile. Accessed 26 Aug 2019.

4. Institute of Environmental Science and Research Ltd. Notifiable Diseases in New Zealand: Annual Report 2016.Porirua, New Zealand 2017. https://surv. 
esr.cri.nz/PDFsurveillance/AnnualRpt/AnnualSurv/2016/2016 AnnualNDReportFinal.pdf. Accessed 28 Aug 2019.

5. World Health Organization. The global view of campylobacteriosis: report of an expert consultation. Utrecht, Netherlands: World Health Organization, Food and Agriculture Organization of th United Nations \& World Organisation for Animal Health; 2013. https://apps.who.int/iris/bitstream/ handle/10665/80751/9789241564601_eng.pdf?sequence=1\&isAllowed=y\%2 0(2013). Accessed 28 Aug 2019

6. Bundesamt für Verbraucherschutz und Lebensmittelsicherheit. Berichte zur Lebensmittelsicherheit: Zoonose-Monitoring 2013. 2015.https://www. bvl.bund.de/SharedDocs/Berichte/03_Zoonosen_Monitoring/2013 zoonosen_monitoring_bericht.pdf?_blob=publicationFile\&v=5. Accessed 28 Aug 2019.

7. Bundesinstitut für Risikobewertung. BfR-Verbrauchermonitor 06 | 2015. https://www.bfr.bund.de/epaper_verbrauchermonitor_2015_deutsch/files/ assets/common/downloads/BfR-Verbrauchermonitor_2015.pdf (2015). Accessed 28 Aug 2019

8. Nestle. Das is(s)t Qualität. 2012. https://www.nestle.de/sites/g/files/pydnoa3 91/files/asset-library/documents/verantwortung/nestle\%20studie/executive summary_studie_2012.pdf. Accessed 28 Aug 2019.

9. Bundesinstitut für Risikobewertung. BfR-Verbrauchermonitor $02 \mid$ 2018. 2018. https://mobil.bfr.bund.de/cm/350/bfr-verbrauchermonitor-02-2018.pdf. Accessed 28 Aug 2019.

10. Cates S, Carter-Young HL, Gledhill E. Changes in Consumer Knowledge, Behavior,and Confidence Since the 1996 PR/HACCP Final Rule. Orlando, FL2002. https://www.rti.org/sites/default/files/resources/haccp_changes_ poster.pdf. Accessed 19 Feb 2019.

11. Allan PD, Palmer C, Chan F, Lyons R, Nicholson O, Rose M, et al. Food safety labelling of chicken to prevent campylobacteriosis: consumer expectations and current practices. BMC Public Health. 2018;18(1):414.

12. Food Standards Agency. Biannual Public Attitudes Tracker 2018. 2018. https://www.food.gov.uk/sites/default/files/media/document/biannualpublic-attitudes-tracker-wave-16-final-270718_1.pdf. Accessed 28 Aug 2019.

13. Lando A, Verrill L, Liu S, Smith E. FDA Food Safety Survey: U.S. Food and Drug Administration; 2016. https://www.fda.gov/media/101366/download. Accessed 28 Aug 2019

14. Hölzl C, Aldrian U. Lebensmittelsicherheit und Hygiene im Privathaushalt: Agentur für Gesundheit und Ernährungssicherheit GmbH. 2011. https:// www.ages.at/fileadmin/AGES2015/Themen/Lebensmittel_Dateien/ Lebensmittelsicherheit_und_Hygiene_im_Privathaushalt_13_12_2013.pdf. Accessed 28 Aug 2019.

15. Lin CTJ, Jensen KL, Yen ST. Awareness of foodborne pathogens among US consumers. Food Qual Prefer. 2005;16(5):401-12.

16. Jay LS, Comar D, Govenlock LD. A national Australian food safety telephone survey. J Food Protect. 1999:62(8):921-8.

17. Bergsma NJ, Fischer ARH, Van Asselt ED, Zwietering MH, De Jong AEl. Consumer food preparation and its implication for survival of campylobacter jejuni on chicken. Br Food J. 2007;109(7):548-61.

18. Kennedy J, Jackson V, Blair IS, McDowell DA, Cowan C, Bolton DJ. Food safety knowledge of consumers and the microbiological and temperature status of their refrigerators. J Food Protect. 2005;68(7):1421-30.

19. Sternisa M, Mozina SS, Levstek S, Kukec A, Raspor P, Jevsnik M. Food safety knowledge, self-reported practices and attitude of poultry meat handling among Slovenian consumers. Br Food J. 2018;120(6):1344-57.

20. European Food Safety Authority. Scientific opinion on quantification of the risk posed by broiler meat to human campylobacteriosis in the EU. 2010. https://efsa.onlinelibrary.wiley.com/doi/pdf/10.2903/j.efsa.2010.1437. Accessed 28 Aug 2019

21. Kaakoush NO, Castano-Rodriguez N, Mitchell HM, Man SIM. Global epidemiology of campylobacter infection. Clin Microbiol Rev. 2015;28(3): 687-720.

22. Bundesanstalt für Landwirtschaft und Ernährung. Versorgung mit Fleisch in Deutschland im Kalenderjahr 2018. 2019. https://www.ble.de/SharedDocs/ Downloads/DE/BZL/Daten-Berichte/Fleisch/Fleisch_2018.xlsx;jsessionid=C4 FB5DE48E8ABDCF931D2096434098FD.1_cid335?_blob=publicationFile\&v= 2.Accessed 28 Aug 2019

23. Yun J, Greiner M, Holler C, Messelhausser U, Rampp A, Klein G. Association between the ambient temperature and the occurrence of human Salmonella and campylobacter infections. Sci Rep-Uk. 2016;6:1-7.

24. Robert Koch Institut. Infektionsepidemiologisches Jahrbuch meldepflichtiger Krankheiten für 2018. 2019. https://www.rki.de/DE/Content/Infekt/Jahrbuch/
Jahrbuch_2018.pdf;jsessionid=B4B6B3E78886C3084EB65186A5C8C638.1_cid3 90? blob=publicationFile. Accessed 18 Dec 2019

25. Fischer M. Möglichkeiten sozialwissenschaftlicher Surveys im Internet : Stand und Folgerungen für Online-Befragungen. 2005. https://kops.uni-konstanz. de/bitstream/handle/123456789/11664/Heft46_OnlineBefragung. pdf?sequence=1. Accessed 28 Aug 2019 .

26. BfR. BfR-Verbrauchermonitor 02/2019. 2019. https://mobil.bfr.bund.de/cm/35 0/bfr-verbrauchermonitor-02-2019.pdf. Accessed 18 Dec 2019.

27. Bartsch L. Analyse des hygienerelevanten Verbraucherverhaltens im Rahmen der Zubereitung gegrillter Speisen: Hochschule Rhein-Waal; 2018. https://opus4.kobv. de/opus4-rhein-waal/frontdoor/index/index/docld/263. Accessed 18 Dec 2019

28. van Velsen $\mathrm{L}$, Beaujean DJ, van Gemert-Pijnen JE, van Steenbergen JE, Timen A. Public knowledge and preventive behavior during a large-scale Salmonella outbreak: results from an online survey in the Netherlands. BMC Public Health. 2014:14:100

29. Smereka J, Szarpak L, Ruetzler K, Schacham Y, Smereka A, Dabrowski M, et al. A multicenter survey on toxoplasmosis knowledge among pregnant women in Poland (the TOWER study). BMC Pregnancy Childb. 2018;18:1-5.

30. Jones JL, Ogunmodede F, Scheftel J, Kirkland E, Lopez A, Schulkin J, et al. Toxoplasmosis-related knowledge and practices among pregnant women in the United States. Infect Dis Obstet Gynecol. 2003;11(3):139-45.

31. Millar PR, de Moura FL, Bastos OMP, de Mattos DPBG, Fonseca ABM, Sudre AP, et al. Toxoplasmosis-related knowledge among pregnant and postpartum women attended in public health units in Niteroi, Rio De Janeiro, Brazil. Rev Inst Med Trop Sp. 2014;56(5):433-8.

32. Pfukenyi $D M$, Chipunga $S L$, Dinginya $L$, Matenga E. A survey of pet ownership, awareness and public knowledge of pet zoonoses with particular reference to roundworms and hookworms in Harare, Zimbabwe. Trop Anim Health Prod. 2010;42(2):247-52.

33. European Food Safety Authority. The European Union summary report on trends and sources of zoonoses, zoonotic agents and food-borne outbreaks in 2016. EFSA J. 2017;15(12):5077-2017.

34. Murray R, Glass-Kaastra S, Gardhouse C, Marshall B, Ciampa N, Franklin K, et al. Canadian consumer food safety practices and knowledge: Foodbook study. J Food Prot. 2017;80(10):1711-8.

35. Zorba NND, Kaptan M. Consumer food safety perceptions and practices in a Turkish community. J Food Protect. 2011;74(11):1922-9.

36. Altekruse SF, Street DA, Fein SB, Levy AS. Consumer knowledge of foodborne microbial hazards and food-handling practices. J Food Protect. 1996;59(3):287-94

37. Bearth A, Cousin ME, Siegrist M. Poultry consumers' behaviour, risk perception and knowledge related to campylobacteriosis and domestic food safety. Food Control. 2014;44:166-76.

38. Ferk CC, Calder BL, Camire ME. Assessing the food safety knowledge of University of Maine students. J Food Sci Educ. 2016;15(1):14-22.

39. Godinez-Oviedo A, Sampedro Parra F, Machuca Vergara JJ, Gutierrez Gonzalez P, Hernandez IM. Food consumer behavior and Salmonella exposure self-perception in the central region of Mexico. J Food Sci. 2019; 84(10):2907-15.

40. Angelillo IF, Foresta MR, Scozzafava C, Pavia M. Consumers and foodborne diseases: knowledge, attitudes and reported behavior in one region of Italy. Int J Food Microbiol. 2001;64(1-2):161-6.

41. Bremer V, Bocter N, Rehmet S, Klein G, Breuer T, Ammon A. Consumption, knowledge, and handling of raw meat: a representative cross-sectional survey in Germany, march 2001. J Food Prot. 2005;68(4):785-9.

42. Bundesinstitut für Risikobewertung. BfR-Verbrauchermonitor 2015 Spezial Antibiotikaresistenzen.https://mobil.bfr.bund.de/cm/350/bfrverbrauchermonitor-2015-spezial-antibiotikaresistenzen.pdf (2015). Accessed 28 Aug 2019.

43. Food Marketing Institute. U.S. Grocery Shopper Trends 2018. Arlington: Food Marketing Institute; 2018.

44. Fein SB, Lando AM, Levy AS, Teisl MF, Noblet C. Trends in U.S. Consumers' safe handling and consumption of food and their risk perceptions, 1988 through 2010. J Food Protect. 2011;74(9):1513-23.

45. United States Department of Agriculture. Food Safety Consumer Research Project: Meal Preparation Experiment Related to Thermometer Use 2018. 2018. https://www.fsis.usda.gov/wps/wcm/connect/cb222383-1e02-471a-865 7-c205eda92acf/Observational-Study.pdf?MOD=AJPERES. Accessed 28 Aug 2019.

46. Bundesinstitut für Risikobewertung. Schutz vor lebensmittelbedingten Infektionen mit Campylobacter. 2019. https://www.bfr.bund.de/cm/350/ 
verbrauchertipps-schutz-vor-lebensmittelbedingten-infektionen-mitcampylobacter.pdf. Accessed 28 Aug 2019.

47. Bundesinstitut für Risikobewertung. Was tun mit dem Huhn?. 2014. http:// www.bfr.bund.de/de/was_tun_mit_dem_huhn_-191706.html. Accessed 28 Aug 2019.

48. United States Department of Agriculture. Campylobacter Questions and Answers. last modified Aug 07,2013. https://www.fsis.usda.gov/wps/portal/ fsis/topics/food-safety-education/get-answers/food-safety-fact-sheets/ foodborne-illness-and-disease/campylobacter-questions-and-answers/ct_ index. Accessed 28 Aug 2019.

49. European Food Safety Authority. EFSA explains zoonotic diseases: Camyplobacter. 2014. https://www.efsa.europa.eu/sites/default/files/ corporate_publications/files/factsheetcampylobacter.pdf. Accessed 28 Aug 2019.

50. Antonise-Kamp L, Friesema IHM, van der Vossen-Wijmenga WP, Beaujean DJMA. Evaluation of the impact of a hygiene warning label on the packaging of poultry. Food Control. 2018;92:86-91.

51. Zühlsdorf A, Jürkenbeck K, Spiller A. Lebensmittelmarkt und Ernährungspolitik 2018: Verbrauchereinstellungen zu zentralen lebensmittelund ernährungspolitischen Themen; 2018.

52. Deutsche Landwirtschafts-Gesellschaft e.V. Verbraucherkompetenz \& Lebensmittelkennzeichnung: Was braucht der Mensch beim Lebensmittelkauf?. 2015. https://www.dlg-verbraucher.info/fileadmin/ downloads/Folder_DLG-Studie_Verbraucherkompetenz_2015.pdf. Accessed 28 Aug 2019.

53. Robert Koch Institut. Infektionsepidemiologisches Jahrbuch meldepflichtiger Erkrankungen für 2016. Berlin. 2017. https://www.rki.de/ DE/Content/Infekt/Jahrbuch/Jahrbuch_2016.pdf?_blob=publicationFile. Accessed 28 Aug 2019.

54. Stratev D, Odeyemi OA, Pavlov A, Kyuchukova R, Fatehi F, Bamidele FA. Food safety knowledge and hygiene practices among veterinary medicine students at Trakia University, Bulgaria. J Infect Public Health. 2017;10(6):778-82.

55. Samapundo S, Thanh TNC, Xhaferi R, Devlieghere F. Food safety knowledge, attitudes and practices of street food vendors and consumers in ho chi minh city, Vietnam. Food Control. 2016;70:79-89.

56. Rossvoll EH, Lavik R, Ueland O, Jacobsen E, Hagtvedt T, Langsrud S. Food safety practices among Norwegian consumers. J Food Protect. 2013;76(11): 1939-47.

57. Langiano E, Ferrara M, Lanni L, Viscardi V, Abbatecola AM, De Vito E. Food safety at home: knowledge and practices of consumers. J Public Health. 2012;20(1):47-57.

58. Tomaszewska M, Trafialek J, Suebpongsang P, Kolanowski W. Food hygiene knowledge and practice of consumers in Poland and in Thailand - a survey. Food Control. 2018;85:76-84.

59. Krack-Roberg E, Rübenach S, Sommer B, Weinmann J. Familie, Lebensformen und Kinder. In: Datenreport 2016, Ein Sozialbericht für die Bundesrepublik Deutschland, vol. 2016. https://www.destatis.de/GPStatistik/ servlets/MCRFileNodeServlet/DEHeft_derivate_00021684/Datenreport2016. pdf\%3Bjsessionid\%3DE5C94A0A9F27899774E66A2BE50E59FF. Accessed 28 Aug 2019.

60. Bundesministerium für Ernährung und landwirtschaft. Deutschland wie es isst. 2016 https://www.bmel.de/SharedDocs/Downloads/Broschueren/ Ernaehrungsreport2016.pdf?_blob=publicationFile. Accessed 28 Aug 2019.

61. Carbas B, Cardoso L, Coelho AC. Investigation on the knowledge associated with foodborne diseases in consumers of northeastern Portugal. Food Control. 2013;30(1):54-7.

62. Alrabadi NI, AL-Massad M, Alboqai O. Food Safety: A Study of Jordanian Consumer's Knowledge and Practices. World Appl Sci J. 2013;22(1):35-40 2013.

63. Marvin DM, Dewey CE, Rajic A, Poljak Z, Young B. Knowledge of Zoonoses among those affiliated with the Ontario swine industry: a questionnaire administered to selected producers, allied personnel, and veterinarians. Foodborne Pathog Dis. 2010;7(2):159-66.

64. Young I, Rajic A, Letellier A, Cox B, Leslie M, Sanei B, et al. Knowledge and attitudes toward food safety and use of good production practices among Canadian broiler chicken producers. J Food Protect. 2010;73(7):1278-87.

65. Bahnson PB, Michalak MM, Miller GY. Pork producers' attitudes, knowledge, and production practices that relate to on-farm food safety. J Food Protect. 2001;64(12):1967-72.
66. Ansari-Lari M, Soodbakhsh S, Lakzadeh L. Knowledge, attitudes and practices of workers on food hygienic practices in meat processing plants in Fars, Iran. Food Control. 2010;21 (3):260-3.

67. Scheinberg J, Radhakrishna RB, Cutter CN. Food safety knowledge, behavior, and attitudes of vendors of poultry products sold at Pennsylvania farmers' markets. J Ext. 2013:51(6):1-12.

68. Arbeitskreis Deutscher Markt- und Sozialforschungsinstitute e. V., Arbeitsgemeinschaft Sozialwissenschaftlicher Institute e.V., Berufsverband Deutscher Markt- und Sozialforscher e. V., Deutschen Gesellschaft für Online-Forschung. Guideline for Online Surveys. 2000. Revised August 2007. http://rat-marktforschung.de/fileadmin/user_upload/pdf/R08_RDMS.pdf.

\section{Publisher's Note}

Springer Nature remains neutral with regard to jurisdictional claims in published maps and institutional affiliations.
Ready to submit your research? Choose BMC and benefit from:

- fast, convenient online submission

- thorough peer review by experienced researchers in your field

- rapid publication on acceptance

- support for research data, including large and complex data types

- gold Open Access which fosters wider collaboration and increased citations

- maximum visibility for your research: over $100 \mathrm{M}$ website views per year

At BMC, research is always in progress.

Learn more biomedcentral.com/submissions 